Relations industrielles

Industrial Relations

\title{
Publications récentes
}

Recent Publications

Volume 21, numéro 1, 1966

URI : https://id.erudit.org/iderudit/027671ar

DOI : https://doi.org/10.7202/027671ar

Aller au sommaire du numéro

Éditeur(s)

Département des relations industrielles de l'Université Laval

ISSN

0034-379X (imprimé)

1703-8138 (numérique)

Découvrir la revue

Citer ce document

(1966). Publications récentes. Relations industrielles / Industrial Relations, 21(1),

115-121. https://doi.org/10.7202/027671ar

Tous droits réservés (C Département des relations industrielles de l'Université Laval, 1966
Ce document est protégé par la loi sur le droit d'auteur. L’utilisation des services d'Érudit (y compris la reproduction) est assujettie à sa politique d'utilisation que vous pouvez consulter en ligne.

https://apropos.erudit.org/fr/usagers/politique-dutilisation/ 


\section{PUBLICATIONS RECENTES RECENT PUBLICATIONS}

\section{GÉNÉRALITÉS}

«An Evaluation of Estimates of Immigration into Canada in the Late Nineteenth Century $\gg$, by James Picket The Canadian Journal of Economics and Political Science, Vol. XXXI, No. 4, November 1965, pp. 499509.

«Des économistes américcins s'interrogent 》, par B. Cazes, Economie \& Humanisme, 163 - septembre-octobre 1965, pp. 28-43.

Recherche Sociale, no 1, septembre-octobre 1965:

- «Le phénomène de socialisation», par Alain Barrère, p. 3;

- «La socialisation vue par les juristes», par René Théry, p. 11;

- « La socialisation vue par les économistes », par André Piettre, p. 17 ;

- Lo socialisation de l'individu», par Pierre Badin, p. 21 ;

- «Signification du mouvement de socialisation », par Jean Caryl, p. 27 ;

- «Les idéologies devant la socialisation », par Jean-Yves Calvez, p. 33 ;

- «Les hésitations du langage et les incertitudes de la pensée », p. 37.

«The Impact of Changes in Agriculture on Political Life in the North American Region », by A.L. Bertrand, Cahiers de L'ISEA, Vol. 8, No. 160, April 1965, pp. 119-133.

«Promotion sociale et éducation permanente », par XXX, Droit Social, 28e année, nos '9-10, septembre-octobre 1965, pp. 469483.

«Some Problems of Education for Choice of Occupation in Czechoslovakia », by Oskar Blaskovic, International Labour Review, Vol. 92. No. 2, August 1965, pp. 106-115.

«Human Resources Planning as a Part of Economic Development Planning », by Jean Mouly, International Labour Review, Vol. 92, No. 3, September 1965, pp. 184-208.

«Changes in Productivity and the Skill-mix 》, by Robert L. Raimon, International Labour Review, Vol. 92, No. 4, October 1965, pp. 314-325.
«The Religious Factor in Canadian Attitudes Toward Bi-Culturalism 》, by Allan Kornberg, The Western Political Quarterly, Vol. XVIII, No. 2, Part I, pp. 285-292.

«Avertissement aux technocrates 》, par Ch Delamare, Promotions, ler Trimestre 1965, no 72 , pp. 7-29.

«Le capitalisme, phase ultime du communisme », par Ch. Delamare, Promotions, $2 e$ Trimestre 1965, no 73, pp. 13-33.

«Automation: Learning to Live With Change », Peter Miller, The Business Quarterly, Summer 1965, Vol. 20, No. 2, pp. 10-27.

«Bilingualism in Montreal: A Demographic Analysis 》, by Stanley Lieberson. The American Journal of Sociology, Vol. $L X X I$, No. 1 , July 1965, pp. 10-26.

«Bicultural and Bilingual Adaptations in French Canada: The Example of Retail Advertising 》, by Frederick Elkin \& Mary B. Hill, The Canadian Review of Sociology and Anthropology, Vol. 2, No. 3, August 1965 pp. 132-149.

«Les tendances démographiques au Canada et aux Etats-Unis», par Jacques Henripin et Nathan Keyfitz, La Revue Canadienne de Sociologie et d'Anthropologie, vol. 2, no 2, mai 1965, pp. 77-92.

«Man as the Highest Value», par A.F. Shishkin, Soviet Sociology, Vol. IV, No. I, Summer 1965, pp. 19-31.

«Entrepreneurship in India », par Phiroze B. Medhora, Political Science Quarterly, Vol. LXXX, No. 4, Decembre 1965.

«Changements technologiques et maind'oeuvre », par Laurent Picard, Québec Industriel, Vol. 20, no 11, novembre 1965, pp. 66-68.

«La rentrée économique et sociale », William Garcin et Marcel Bertaud, Professions, 7le année, no 574, septembre 1965, pp. 11-37.

«L'entreprise face au phénomène de socialisation », Serge Guibert et Philippe de Woot, 
Relations Industrielles, vol. 21, No 1

Professions, 7le année, no 575, octobrenovembre 1965, pp. 16-23.

«Un monde à construire », numéro spécial de Bulletin social des Industriels, 37 e année, no 320, octobre 1965, pp. 453-508.

«L'éducation ouvrière et la politique de I'OIT, LABOR, 38e année, no 4, 1965, pp. $215-222$

«Automation, développement économique et emploi 》 Labor, 38e année, no 4, 1965, pp. 222-228.

Employer Associations Engaged in Collective Bargaining in New York State, New York State Department of Labor, Division of Research and Statistics, Publication No. B-150, October 1965, pp. 78.

Out of Work - A Guide Through Unemployment in New York State, by $N$. Thurber \& Duncon M. MacIntyre, New York State School of Industrial and Labor Relations, Cornell University, Bulletin 53-3, Revised August 1965, pp. 1-37.

«Industrial Democracy in the Affluent Society $\gg$, by Adolf Sturmthal, Reprint Series No. 153, Institute of Labor and Industrial Relations, University of Illinois Bulletin, pp. $1-10$.

\section{TRAVAIL ET MAIN-D'OEUVRE}

«Labor Skills and International Trade: Evaluating Many Trade Flows with a Single Measuring Device », by Donald B. Keesing, The Review of Economics and Statistics, Vol. XLVII, No. 3, August 1965, pp. 287295.

«Effects of Professional Licensing Arrangements on Interstate Labor Mobility and Resource Allocation », by Arlene S. Holen, The Journal of Political Economy, $\mathrm{Vol}$. L.XXIII, No. 5, October 1965, pp. 492-499.

«Réflexions sur la population active masculine «techniquement nécessaire » en agriculture », par P. Coutin, Cahiers de I'ISEA no 155 , novembre 1964, pp. 57-69.

«Quelques aspects de l'évolution de la population active masculine agricole de 1946 à 1962 》, par P. Echard, Cahiers de I'ISEA, no 155 , novembre 1964, pp. 69-109.

«A Critique of Manpower Planning and Educational Change in Africa », by Webster C. Cash, Economic Development and Cultural
Change, Vol. XIV, No. 1, October 1965, pp. 33-48.

«Les titulaires d'un diplôme d'enseignement technique ou professionnel dans lo population active en $1962 \%$, par Claude Vimont et Jacques Baudot, Population, $2 \mathrm{Ce}$ année, no 5, septembre-octobre 1965, pp. 763-785.

"Les mouvements de Populations》, numéro spécial de Informations Sociales, 19 e onnée, no 9, septembre 1965, pp. 4-84.

«Surplus » Agricultural Labor and Development $\gg$, by Morton Paglin, The American Economic Review, Vol. LV, No. 4, September 1965, pp. 815-834.

«Australian Unemployment», by C. Forster, The Economic Record, Vol. 41, No. 95, September 1965, pp. 426-451.

«Manpower Shortages and Active Manpower Policies in Europe in $1964 \gg$, International Labour Review, Vol. 92, No. 1, July 1965, pp. 1-21.

«The Scope for Manpower Analysis in Planning Production in Certain African Countries 》, by K.A. Blakey, International Labour Review, Vol. 92, No. 5, November 1965, pp. 380-397.

«Employment of Women in the Czechoslavak Socialist Republic », by Milena Srnska, International Labour Review, Vol. 92, No. 5, November, pp. 397-410.

«Retraining in the United States: Problems and Progress 》, by Ida Russakoff Hoos, International Labour Review, Vol. 92, No. 5, November 1965, pp. 410-426.

Industrial Relations, Vol. 5, No. 1, October 1965. A symposium: Professional and White Collar Unionism: An International Comparison

- $\ll$ The Prospects for White-Collar Union Growth », Everett M. Kassalow, p. 37.

- «Professionals and Unions in Isroel 》, Joseph Ben-David, p. 48.

- «Professional Organization in Great Britain 》, Ken Prandy, p. 67.

- White-Collar Unions and the Norwegian Labor Movement 》, Egil Fivelsdal, p. 80. - «Australian Professional and WhiteCollar Unions 》, Ross M. Martin, p. 93. - The White-Collar, Blue-Collar Alliance in Japan » Solomon B. Levine, p. 103.

- «A Quasi-Union: West Germany University Association 》, Wolf D. Fuhrig, p. 116.

- -The AAUP as a Professional Occupational Association 》, George Strauss, p. 128. 
- Employed Graduate Students Organize at Berkeley 》, Sidney Ingerman, p. 141.

«Structure de l'emploi et conjoncture au Canada», Conjoncture Economique Canadienne, vol. 3, no 6, décembre 1965, pp. 2962.

"Young Adults as Wage Earners and Consumers $»$, by James W. Duncan, Business and Government Review, Vol. VI, No. 5 , September-October 1965, pp. 20-28.

«A Survey of the Development of Manpower Planning Policies 》, by D.T. Bryant, British Journal of Industrial Relations, Vol. III, No. 3, November 1965, pp. 279-291. «L'emploi des femmes》, Labor, 38e année, no 4, 1965, pp. 228-231.

«An Insight into Structural Unemployment The Experience of a Minority Group in a Prosperous Community $\gg$, by Walter J. Gershenfeld, Economic and Business Bulletin, Temple University School of Business, Vol. 18, No. 1, September 1965, pp. 21-28.

«Critical Issues in American Manpower Policy and Practice », by Frederick Harbison, Industrial Relations Section Department of Economics, Princeton University, pp. 1-14.

\section{DIRECTION DU PERSONNEL}

«Le contrôle hiérarchique des décisions de I'Inspecteur du travail relatives au licenciement des représentants du personnel $\gg$, par G. de Lestang, Droit Social, 28e année, nos 9-10, septembre-octobre 1965, pp. 502508.

«Management Training for Organization Development 》, par Bernard Portis, The Business Quarterly, Summer 1965, Vol. 30, No. 2, pp. 44-55.

«Examinations and Training》, par H.F. Heath, Public Administration, Vol. XXIV, No. 3, September 1965, pp. 230-249.

«Effective Discipline - A Positive Profit Tool », par Paul W. Brockley, Personnel Journal, Vol. 44, No. 9, October 1965, pp. 475-480.

"The Other Half of Recruiting 》, by Orlando Behling, Personnel Journal, Vol. 44, No. 9, October 1965, pp. 480-485.

«A New Concept for Training Industrial Relations Managers 》, by Lewis R. Zeyher, Personncl Journal, Vol. 44, No. 10, November 1965, pp. 531-537.
«Management Theory Z Applied to Systems of Management Training, Salary and Wage, and Promotion - Part $\|$ of Two Parts 》, by J.M. Rosenfeld and M.J. Smith, Personnel Journal, Vol. 44, No. 10, November 1965, pp. 543-551.

"The Care and Feeding Responsibilities of Personnel $\gg$, by William E. FitzGerald, Personnel Journal, Vol. 44, No. 11, December 1965, pp. 592-597.

British Journal of Industrial Relations, Vol. III, No. 3, November 1965:

Symposium on Planning for Recruitment and Employment:

- A Simple Arithmetical Approach to Career Planning and Recruitment $》, S$ Wood, pp. 291-301.

- Models for Planning Recruitment and Promotion of Staff », Andrew Young, pp. $301-311$.

- «Wage and Salary Policies for Recruitment 》, Michael P. Fogarty, pp. 311-326.

«Measurement and Appraisal of the Performance of Foremen 》, by G. Westerlund and $L$. Stromberg, British Journal of Industrial Relations, Vol. III, No. 3, November 1965, pp. 345-363.

«The Flow of Occupational Supply and Recruitment $\gg$, Peter M. Blau, American Sociological Review, Vol. 30, No. 4, August 1965, pp. 475-491.

«A New Look at Management Training》, by Neil $H$. Cheek, Jr., and Leopold ' $W$ '. Gruenfeld, Reprint Series No. 176, New York State School of Industrial and Labor Relations, pp. 1-4.

«Computers and the Personnel Department $\gg$, by David Dace, Personnel Management, Vol. XLVII, No. 374, December 1965, pp. 201-207.

«Organization Theory and the Personnel Manager », by T.T. Paterson, Personnel Management, Vol. XLVII, No. 374, December 1965, pp. 207-213.

«Some Aspects of Training in the Construction Industry 》, by J.A. Brock. Personnel Management, Vol. XLVII, No. 374, December 1965, pp. 221-224.

«Planning Ahead in Company Manpower 》, D.G. Willmot, The Canadian Personnel \& Industrial Relations Journal, Vol. 12, No. 4, October 1965, pp. 23-29. 


\section{ORGANISATION ET GESTION DE L'ENTREPRISE}

«Equitcble Allocation of Merit Increase Dollars - «Comparison of Mid-Points》 Inadequate as Effective Method of Distribution 》, by Michael R. Losey, Personnel Journal, Vol. 44, No. 10, November 1965, pp. $537-543$.

«Critical Path Scheduling: A Comprehensive Look $\gg$, by Rein Peterson, The Business Quaterly, Summer 1965, Vol. 30, No. 2, pp. 70-85.

«La réforme de l'entreprise soviétique: mythes et réalités », par Jean-Louis Guivert, Promotions, 2 e trimestre 1965, no 73, pp. 3359.

«Le vade-mecum de l'administrateur ou l'administration au ras du sol $\gg$, por $J$. Luhan, Promotions, ler trimestre 1965, no 72, pp. 73-89.

«Division du travail et élargissement des tâches 》, par R. Perol, La Revue Administrative, 18e année, no 107, septembre-octobre 1965, pp. 517-521.

«Une maladie de la production: I'Absentisme 》, par P. Sartin, La Revue Administrative, 18e année, no 105, mai-juin 1965, pp. 316-321.

«Simulation: Techniques \& Applications》, by James B. Cloonan, Business and Government Review, Vol. VI. No. 6, NovemberDecember 1965, pp. 18-27.

«Accounting and Decision Making »" by Wilber C. Haseman, Business and Government Review, Vol. VI, No. 6, NovemberDecember 1965, pp. 27-34.

«Managerial Economics and Management Decisions》, by C.M. Birch, The Business Quarterly, Fall 1965, Vol. 30, No. 3, pp. 7076

«The Nature of a Career Crisis», by Eugene Emerson Jennings, Business Topics, Autumn 1965, Vol. 13, No. 4, pp. 43-58

«The Mastery of Management», by John J. Corson, Public Administration Review, Vol. XXV, No. 2, June 1965, pp. 168-172.

«La liberté des cadres», par M.L. Hynes, Québec Industriel, vol. 20, no 12, décembre 1965, pp. 55-58.

«La délégation de l'autorité », par M. Jean L'Espérance, Québec Industriel, Vol. 20, no. 12 , décembre 1965, pp. 62-66
«Eight New Careers that Pace Today's Booming Technology $\gg$, Plant Administration \& Engineering, Vol. 25, No. 10, October 1965, pp. 58-62.

«New Organization Trends Move In », Plant Administration \& Engineering, Vol. 25, No. 12, December 1965, pp. 32-35.

"What an Executive Should Know about Scientists 》, by Harry Levinson. Think, Vol. 31, No. 5, September-October 1965, pp. 6-11.

«Système économique et statut de l'entreprise, por R. Henrion, Annales de Sciences économiques appliquées, XXllle année, no 3, août 1965, pp. 337-365.

«L'évolution des théories en administration 》, par Laurent Picard, L'Actuallité économique, 4le année, no 3, octobre-décembre 1965, pp. 383-418.

\section{QUESTIONS ÉCONOMIQUES}

«Dualisme et disparités régionales», par Giancarlo Mazzochi, Revue Economique, no 5, septembre 1965, pp. 708-731.

«Quelques instruments d'analyse de la répartition des revenus appliqués à l'évolution belge de 1953 à $1962 »$, par Michel Falise, Revue Economique, no 5, septembre 1965, pp. 777-796.

«Lifetime Income and Economic Growth», by H.P. Miller, The American Economic Review, Vol. LV', No. 4, September 1965, pp. $834-844$.

«The Demand Curve for a Factor of Production: Comment», by D.M. Winch, The American Economic Review, Vol. LV', No. 4, September 1965, pp. 856-861.

«Wage Adjustments in the Appalachion States», by David E. Kaun, The Southern Economic Journal, Vol. XXXII, No. 2, October 1965, pp. 127-137.

«The Breakup of the Maximization Principle », by Gerald L. Nordquist, The Quarterly Review of Economics \& Business, Vol. 5, No. 3, Fall 1965, pp. 33-47.

«Les salaires》, par Jacqueline BarroteauxPonthieu, Revue d'Economie Politique, 75 e année, no 4-5, juillet-octobre 1965, pp. 1044-ios7.

«Wage Determination in Australia: Basic Wage and Total Wage Inquiries, $1964 \gg$, Internotional Labour Review, Vol. 92, No. 2, August 1965, pp. 128-141. 
«Profit and «Profits》, by $Y$. Liberman Labour Monthly, Vol. XLVII, No. 12, December 1965, pp. 542-548.

《La signification du terme de productivité 》, par R.W. Fenske, Revue de la Mesure de la Productivité, no 42, août 1965, pp. 17-25.

«An American Economist Looks at Canada》, by James A. McCullough, The Business Quarterly, Summer 1965, Vol. 30, No. 2, pp. 27-36.

《La société industrielle et la productivité 》, par J. Dofny, Québec Industriel, vol. 20, no 11 , novembre 1965, pp. 68-77.

\section{RELATIONS INDUSTRIELLES}

«Employers' Associations and Collective Bargaining in the German Federal Republic », by Ronald F. Bunn, The Southwestern Social Science Quarterly, Vol. 46, No. 2, September 1965, pp. 155-164.

«Criticism of the Japanese Congress of Industrial Labor Organizations », by Matsuta Hosoya, Journal of Social and Political Ideas in Japan, Vol. III, No. I, April 1965, pp. 34-38

«La négociation des conventions collectives dons les pays de la C.E.E. », par R. Allusson, Droit Social, 28e année nos 9-10, septembre-octobre 1965, pp. 492-502.

«Compulsory Arbitration and Collective Bargaining $\gg$, by Sir Richard Kirby, Public Administration, Vol. XXIV, No. 3, September 1965, pp. 200-214.

«Plant Bargaining in Steel: North East Case Studies », by J.E.T. Eldridge, The Sociological Review, Vol. 13, No. 2, July 1965, pp. $131-149$.

«Le Comité d'entreprise», par M. C. Perrault, Québec Industriel, Vol. 20, no 12, décembre 1965, pp. 58-62.

«The Sources and Evolution of Indian Labour Relations Policy 》, by Van D. Kennedy, Indian Journal of Industrial Relations, Vol. I, No. I, July 1965, pp. 15-41.

«Consensus, Ideology and Labor Relations》, by James O. Morris, Reprint Series, No. 175, New York State School of Industrial and Labor Relations, pp. 301-315.

Negotiating Labor-Management Contracts, Donald E. Cullen, Bulletin 56, New York
State School of Industrial and Labor Relations, Cornell, pp. 1-56.

«Labor Participation in Management», by Milton Derber, Reprint Series No. 154 Institute of Labor and Industrial Relations, University of Illinois Bulletin, pp. 1-9.

\section{SOCIOLOGIE-PSYCHOLOGIE}

«Economie rurale et problèmes humains du développement », par V. Drachoussoff, Cahiers de I'ISEA, vol. 8, no 160, avril 1965.

«On Work, Alienation, and Leisure », B.B. Seligman, The American Journal of Economics and Sociology », Vol. 24, No. 4, October 1965, pp. 337-360.

"Some Reflections on the Different Attitudes of Men and Women Towards Work 》 Magdalena Sokolowska, International Labour Review, Vol. 92, No. 1, July 1965, pp. 35-51.

«The Application of Industrial psychology to Developing Countries », H.G. Maule, International Labour Review, Vol. 92, No. 4, October 1955, pp. 283-298.

"The Relations Between Work and NonWork Among Technicians » by Stephen Cotgrove, The Sociological Review, Vol. 13, No. 2 , July 1965, pp. 121-131.

«Mood and Emotional Problems: Effect on the Individual and the Business Organization » by G. Edgar Hobbs, M.D., The Business Quarterly, Fall 1965, Vol. 30, No. 3, pp. 57-64.

"Let's Stop Worrying about Aptitudes and Look at Attitudes » by Robert M. Hecht, Joel E. Aron, and Sidney Lirtzman, Personnel Journal, Vol. 44, No. 11, December 1965, pp. 616-620.

« Community of Residence and Occupational Choice " by William $H$. Sewell and Alan $M$. Orenstein, The American Journal of Sociology, Vol. LXX, No. 5, March 1965, pp. 551 564.

American Sociological Review, Vol. 30, No. 5, October 1965.

- Dual Leadership in Complex Organizations », Amitai Etzioni, pp. 688-699.

- "Demotion in Industrial Management», Fred H. Goldner, pp. 714-725.

- Career Anchorage: Managerial Mobility Motivations », Curt Tausky and Robert Dubin, pp. 725-735. 
— Academic Ability, Higher Education, and Occupational Mobility », Bruce Eckland, pp. 735-747.

«Occupational Mobility in the United States $\%$, by Otis Dudley Duncan, American Sociological Review, Vol. 30, No. 4, August 1965, pp. 491-499.

"Value Orientation, Role Conflict, and Alienation from Work", Louis A. Zurcher, Jr., Arnold Meadow, and Susan Lee Zurcher, American Sociological Review, Vol. 30, No. 4, August 1965, pp. 539-548.

"A propos des relations humaines dans l'entreprise » J. Pierre, Annales de Sciences économiques appliquées, XXIlle année, no 3 , août 1965, pp. 367-380.

"Job Satisfaction and Absenteeism " by Durganand Sinha, Indian Journal of Industrial Relations, Vol. I, No. 1, July 1965, pp. 89-100.

"The Need for and Methods of Organizing Behavioural Research », by John C. Sawatsky, The Canadian Personnel \& Industrial Relations Journal, Vol. 12, No. 4, October 1965, pp. 29-37.

«Can They Motivate Profit?》, Plant Administration \& Engineering, $\mathrm{Vol} .25$, No. 12, December 1965, pp. 28-32.

"Morale et Efficacité 》 par Ph. Laurent, S.J., Professions, 7 le onnée, no 575, octobrenovembre 1965, pp. 9-16.

"Workmen's Compensation and the Emotionally Disturbed Employee », by Harrison $M$. Trice and James A. Belasco, ILR Research, Vol. XI, No. 2, November 1965, pp. 3-7.

"Some Correlates of Risk Taking 》, by Lawrence K. Williams, Reprint No. 177, ILR New York State School of Industrial and Labor Relations, pp. 297-310.

"A Linear Model of Job Satisfaction " by Charles L. Hulin and Patricia Cain Smith, Reprint Series No. 155, Institute of Labor and Industrial Relations, University of IIInois Bulletin, pp. 209-216.

\section{SYNDICALISME}

"Trade Unions and the Chinese Communists », by Klaus $H$. Pringsheim, The Southwestern Social Science Quarterly, Vol. 46, No. 2, September 1965, pp. 111-122.
"Unionism, Wages, and Cost-Push " by $K$ O. Alexcnder, The American Journal of Economics and Sociology, Vol. 24, No. 4, October 1965, pp. 383-395.

«Le mouvement ouvrier irlandais» par J.W. Boyle, Le Mouvement Social, no 52, juilletseptembre 1965, pp. 33-55.

"L'histoire ouvrière en Grande-Bretagne » par F. Bédarida, Le Mouvement Social, no 52, juillet-septembre 1965, pp. 55-59.

"The Royal Commission on Trade Unions" J.E. Mortimer, Labour Monthly, Vol. XLVII, No. 5, May 1965, pp. 204-209.

"T.U.C.: Lessons for Labour », Ralph Bond, Labour Monthly, Vol. XLVII, No. 10, October 1965, pp. 446-450.

"British Labour in Marx's Day », Andrew Rothstein, Labour Monthly, Vol. XL.VII, No. 10, October 1965, pp. 474-479.

"Le syndicalisme dans l'entreprise " A. Aumonier, Droit Social, 28e année, no 11, novembre 1965, pp. 543-546.

"Confédération de syndicats. Pouvoir du Congrès extraordinaire de modifier les statuts à la majorité. Note de jurisprudence " J. Brethe de la Gressaye, Droit Social, 28e année, no 11, novembre 1965, pp. 550-556.

«American Labour's Political Freedom: A British View " by Vivian Vale, Political Studies, Vol. XIII, No. 3, October 1965, pp. $281-300$

"White-Collar Unionization: A Conceptual Framework" by R.M. Blackburn and K. Prandy, The British Journal of Sociology, Vol. XVI, No. 2, June 1965, pp. 11-123.

"Un groupe de pression en action: Les symdicats universitaires devant le projet Billères de réforme de I'enseignement (1955-1959) 》 par F.-G. Dreyfus, Revue Française de Science Politique, vol. XV, no 2, avril 1965, pp. 213-251.

"An Evaluation of the Impact of Unions on Wage Differential », by Edward R. Curtin, ILR Research, Vol. XI, No. 2, November 1965, pp. 7-12.

"Le syndicalisme et la représentation des cadres » par Marcel Laloire, Bulletin social des Industriels, 37e année, no 319, aoûtseptembre 1965, pp. 408-412.

"Le chef d'entreprise et le syndicalisme " par C.E. Lebrun, Québec Industriel, vol. 20, no 12 , décembre 1965, pp. 50-52. 
"Les répercussions de la syndicalisation " par André Déom, Québec Industriel, vol. 20, no 12, décembre 1965, pp. 52-55.

«Situation syndicale dramatique en Bolivie » Labor, 38e année no 3, mai-juin 1965, pp. $161-167$.

Labor Organization in New Jersey, Leo Troy, Research Program Institute of Management and Labor Relations, Rutgers - The State University, pp. 1-28.

\section{LÉGISLATION DU TRAVAIL}

" Le mouvement ouvrier et la législation sociale » par Michel Collinet, Revue d'Economie Politique, 75 e année, no $4-5$, juilletoctobre 1965, pp. 1057-1072.

"Jurisprudence commentée », Jean Savatier, Droit Social, 28e année nos 9-10, septembre 1965, pp. 508-514 et no 11, novembre 1965, pp. $556-564$.

\section{SÉCURITÉ SOCIALE}

«La sécurité sociale» par Etienne Antonelli, Revue d'Economie Politique, 75 e année, nos 4-5, juillet-octobre 1965, pp. 1072-1084.

"Croissance économique et bien-être » par A. Weisskopf, Economie $\mathcal{E}$ Humanisme, no 163, septembre-octobre 1965, pp. 3-16.

"L'exercice par un salarié d'une activité indépendante à titre accessoire », G. LyonCaen, Droit Social, 28 e année, no 11, novembre 1965, pp. 564-569.

\section{I VRES REC US BOOKS RECEIVED}

ALLUSSON, Roger, Les Cadres supérieurs dans I'entreprise, Entreprise Moderne d'Edition, 4, rue Cambon, Paris ler, 1965. 144 pages.

SCOTT, William G., The Management of Conflict . . Appeal Systems in Organizations, Richard D. Irwin, Inc., Homewood, Illinois, 1965. 129 pages.

SCOTT, W.H., L'Automatisation du travail de bureau : problèmes administratifs et hu-
"Livelihood Guarantee Funds in Belgium ", International Labour Review, Vol. 92, No. 2, August 1965, pp. 141-148.

"Income Redistribution and Social Security: Interpretation of a Japanese Survey " T. Higuchi, International Labour Review, Vol. 92, No. 3, September 1965, pp. 208-224.

"Some Remarks on the Development of Social Security in Czechoslovakia \#, Ladislav Pisca, International Labour Review, Vol. 92, No. 3, September 1965, pp. 224-234.

«Political Structure, Economic Development and National Social Security Programs », by Philips Cutright, The American Journal of Sociology, Vol. LXX, No. 5, March 1965 pp. 537-551.

"The Role of Collective Bargaining in France: The Case of Unemployment Insurance » by Frederic Meyers, British Journal of Industrial Relations, Vol. III, No. 3, November 1965, pp. 363-392.

"L'orientation scientifique des loisirs des salariés » Docteur Stanislas Burstin, Travail-Humanisme, nos 1-2, 1965, pp. '1-16.

"L'observation du comportement au travail dans l'étude des accidents », Docteur Roger Noesen, Travail-Humanisme, nos 1 et 2, 1965, pp. 16-31.

"Le régime d'assurance sociale des salariés en Inde », par V.N. Rajan, Bulletin de I'Association internationale de la Sécurité sociale, année XVIII, nos 5-6, mai-juin 1965, pp. 177-197.

mains, Organisation de coopération et de Développement économiques, 2, rue AndréPascal, Paris, 1965. 116 pages.

LING, Cyril C., The Management of Personnel Relations, History and Origins, Richard D. Irwin, Inc., Homewood, Illinois, 1965. 554 pages.

Crime and Its Treatment in Canada, Edited by W.T. McGrath, Macmillan of Canada, Toronto, 1965. 510 pages. 